\title{
The role of buzz and viral marketing strategic on purchase intention and supply chain performance
}

\author{
Muhajir $^{a^{*}}$, Hajar Mukaromaha ${ }^{\text {a }}$, Fathudin ${ }^{a}$, Kristi Liani Purwanti ${ }^{\text {b }}$ Yazid Al Ansori ${ }^{\text {a }}$, Mochammad \\ Fahlevi $^{\mathrm{c}}$, Siti Rosmayati ${ }^{\mathrm{d}}$, Rahman Tanjung ${ }^{\mathrm{e}}$, Ratu Hedy Syahidah Budiartif Rosyadi $^{\mathrm{g}}$ and Agus \\ Purwanto $^{\text {h }}$
}

${ }^{a}$ Sekolah Tinggi Agama Islam An-Nawawi Purworejo, Indonesia

${ }^{b}$ UIN Walisongo Semarang, Indonesia

${ }^{c}$ Management Department, BINUS Online Learning, Bina Nusantara University, Indonesia

'Institut Manajemen Koperasi Indonesia, Indonesia

${ }^{e}$ STIT Rakeyan Santang Karawang, Indonesia

${ }^{f}$ Universitas Pasundan, Indonesia

${ }^{g}$ Universitas Wiralodra, Indonesia

${ }^{h}$ AGUSPATI Research Instituta, Indonesia

A B S T R A C T

\begin{tabular}{l} 
Article history: \\
Received July 25, 2021 \\
Received in revised format \\
September 24, 2021 \\
Accepted October 292021 \\
Available online \\
November 152021 \\
\hline Keywords: \\
Viral Marketing \\
Buzz Marketing \\
Purchase Intention \\
Supply Chain Performance
\end{tabular}

Supply Chain Performance

\begin{abstract}
The purpose of this study is to analyze the effect of viral marketing and purchase intention, the influence between viral marketing and supply chain performance, the influence buzz marketing and purchase intention, the positive buzz marketing and supply chain performance, and the influence between purchase intention and supply chain performance. This study uses quantitative methods and data analysis techniques Structural Equation Modeling Equation Modeling using SmartPLS 3.0 software. The sample selection method used the snowball sampling method. Online questionnaires were sent to respondents as many as 120 Freight Forwarders in DKI Jakarta. Based on data analysis, it was found that there is a positive influence between viral marketing and purchase intention, there is a positive influence between viral marketing and supply chain performance, there is a positive influence between buzz marketing and purchase intention. There is a positive influence between marketing buzz and supply chain performance. There is a positive influence between purchase intention and supply chain performance. The novelty of this research is a model of the relationship between viral and buzz marketing on purchase intention and supply chain performance and the results of this study can be applied in other organizations and in other countries.
\end{abstract}

\section{Introduction}

In the era of industry 4.0 the business developments in the forwarder company have increased, where forwarder companies are required to be able to fulfill consumer desires in achieving the desired service quality. According to Carl et al. (2006) service quality is built on the comparison of two main factors, namely consumer perceptions of the real service they receive (perceived service) with the desired service (expected service). If the reality is more than expected then the service can be said to be of quality, whereas if the reality is less than expected then the service is said to be of poor quality. If the reality is the same as the expectation, the service is said to be satisfactory. According to Vianna et al. (2016) service quality can be defined as how far the difference between reality and customer expectations for the services they receive/obtain. With these conditions, it requires forwarder companies to be able to analyze the service quality of their products if they want to remain competitive in the global market and be liked by consumers. According to Trivedi et al. (2017), Vianna et al. (2016) One of the service industries that has recently been increasing is the forwarder service industry, where the main products include:

* Corresponding author

E-mail address: muhajirmadruslam@gmail.com (Muhajir)

(C) 2022 Growing Science Ltd. All rights reserved.

doi: $10.5267 /$ j.uscm.2021.11.002 
export products (delivery of goods from within the country to abroad), imports (delivery of goods from abroad to domestic), ocean freight products (delivery of goods by sea), air freight products (delivery of goods by air), land transportation products (delivery by land transportation), customs clearance products (processes customs clearance) and product logistics (warehousing).

According to Carl et al. (2006), Prahiawan et al. (2021, 2022) and Goyal et al. (2018) social media users are growing rapidly all over the world, including in Indonesia. For organizations or companies, social media is widely used as a medium or tool for conducting marketing communications. Unlike traditional media which is only able to implement one-way communication, social media is able to implement two-way or more communication. Using social media as a marketing communication tool is not only like using the internet and technology but must use communication tactics and strategies. According to Shin et al. (2016), Trivedi el. (2017), Vianna et al. (2016) Tactics and strategies are prepared based on the capabilities possessed and the targets to be achieved. By using social media capabilities optimally, maximum targeted results can be achieved. According to Rabidas et al. (2019), it is very important to know in depth the capabilities of social media as a marketing communication tool, what capabilities social media has so that it can be used as a marketing tool, and what results can be achieved when using social media as a marketing tool. According to Haryani et al. (2015), Holdford et al. (2004)) defines social media as a group of internet-based applications that use the ideology and technology of Web 2.0, where users can create or exchange information on the application. According to Shin et al. (2016) Some social media that are very popular and have millions of users in Indonesia are Facebook, Twitter, Instagram, YouTube, Blogs, and others. According to Rudyanto et al. (2021); Haudi et al. (2021); Purba et al. (2021); Wijaya et al. (2021), Social media allows users to communicate with millions of other users. For marketers, this is a huge potential and opportunity to be used as a marketing communication tool. Social media makes sharing information between users easier. With great potential and has been widely used by large companies, there will be questions that are the topic of this study, namely what the antecedents and consequences of marketers are using social media as a marketing communication tool. According to Rouva et al. (2016), Satrio et al. (2020), Shin et al. (2016) social media can be accessed anytime and anywhere, because apart from being accessed via a computer, it can be accessed via mobile/smart phones. This provides an opportunity for marketers to be able to carry out marketing communications anytime and anywhere.

According to Reichstein and Brusch (2019), Rouva et al. (2016), Satrio et al. (2020), Shin et al. (2016) categorize antecedents or motivations for marketers to use social media as a marketing communication tool. Antecedents are described as follows: Customer Engagement, Individual motivation to use social media is to interact socially. This gives organizations the opportunity to establish interactions between brands/companies and consumers through social media. Coupled with the ability of social media that could carry out two-way communication. Based on Notaranonio et al. (2009), Sawaftah et al. (2020), Oosterwijk et al. (2005), Rabidas et al. (2019) customer engagement is the relationship between customers and organizations, where customers do not only consume, but also contribute and be creative to the organization or brand. Where these activities start from reading messages, two-way communication, participating, and giving online recommendations. According to Rabidas et al. (2019), Reichstein and Brusch (2019), Rouva et al. (2016), Satrio et al. (2020), Shin et al. (2016), Trivedi et al. (2017), Vianna et al. al. (2016) in conducting engagement through social media, organizations are expected to do so in a friendly, fun, open, empathetic, and supportive way. In addition, the organization must be able to hold the nature of being honest, sincere, trustworthy, and responsible. By conducting customer engagement, customers indirectly participate in conducting marketing communications for the company. Social media allows users to communicate with millions of other users. According to Carl et al. (2006), Goyal et al. (2018) uniting Brands and consumers in social media is currently growing and other social media are growing, for example Path and Instagram. According to Trivedi et al. (2017), Vianna et al. (2016) The social media application is used by marketers as a communication tool that is integrated with other communication tools so that relationships with consumers can be maintained. According to Oosterwijk et al. (2005), Rabidas et al. (2019) Social media is a marketing communication tool that has great capabilities because of its wide-ranging communication skills, ability to share information, and break geographic boundaries. Social media is not a substitute for traditional media, but is integrated with traditional media to get more optimal results. According to Gunawan et al. (2015), Haryani et al. (2015) determining the target or output to be achieved in using social media as a marketing tool is very important, knowing it can formulate effective and efficient strategies to suit marketing objectives. By knowing the capabilities of social media (antecedents), marketers can formulate marketing strategies in accordance with marketing objectives.

\subsection{Relationship of Viral Marketing to Purchase Intention}

Viral marketing is one of the advantages of social media compared to traditional media. According to Carl et al. (2006) viral marketing is creating marketing messages or advertising that aims to be disseminated through online word of mouth (WOM). Sharing information, such as photos, videos or articles, which was previously done on certain Web Sites, has now migrated to social media. According to Carl et al. (2006), Goyal et al. (2018), Gunawan et al. (2015) Viral Marketing has a positive and significant effect on Purchase Intention. According to Haryani et al. (2015), Holdford et al. (2004), Leila et al. (2013) Viral Marketing has a positive and significant effect on Purchase Intention.

Hypothesis 1: Viral Marketing has a positive and significant effect on Purchase Intention. 


\subsection{The Relationship of Viral Marketing to Supply Chain Performance}

According to Satrio et al. (2020), Shin et al. (2016) there are several factors that influence advertising on social media to get a positive attitude from social media users, namely informative, entertaining, self-brand congruity, and peer influence. According to Leila et al. (2013), Liu et al. (2019), Mohr et al. (2017), Notarantonio and Quigley (2009) Viral Marketing has a positive and significant effect on Supply Chain Performance. According to Sawaftah et al. (2020), Oosterwijk et al. (2005), Rabidas et al. (2019) have a positive and significant effect on Supply Chain Performance.

Hypothesis 2: Viral Marketing has a positive and significant effect on Supply Chain Performance.

\subsection{Relationship between Buzz Marketing and Purchase Intention}

According to Carl et al. (2006), Goyal et al. (2018) buzz marketing uses WOM to spread consumer experiences, opinions, or information about a brand or company to fellow social media users. The study also explained that buzz marketing is divided into two types, namely, consumers to consumers or buzzers to consumers. According to Notarantonio and Quigley (2009), Sawaftah et al. (2020) Buzzer is a brand ambassador or person who appoints a company to represent the company. One of the reasons customers join social media is to share their experiences with other users. According to Rabidas et al. (2019), Reichstein et al. (2019) Buzz Marketing has a positive and significant effect on Purchase Intention. According to Rouva et al. (2016), Satrio et al. (2020) Buzz Marketing has a positive and significant effect on Purchase Intention.

Hypothesis 3: Buzz Marketing has a positive and significant effect on Purchase Intention.

\subsection{Buzz Marketing's Relationship to Supply Chain Performance}

According to Notarantonio and Quigley (2009), Sawaftah et al. (2020), Oosterwijk et al. (2005), Rabidas et al. (2019), Reichstein et al. (2019) Online word of mouth is a potential marketing communication tool, but there are also risks for marketers that marketers must face from online word of mouth, namely online recommendations. which is negative. According to Rabidas et al. (2019), Reichstein et al. (2019) companies advertise on social media to increase awareness, in addition, several companies also appoint brand ambassadors to write or share recommendations on social media. Marketers do this because of the ability of social media to do viral and buzz marketing. According to Oosterwijk et al. (2005), Rabidas et al. (2019) Buzz Marketing has a positive and significant effect on Supply Chain Performance. According to Reichstein et al. (2019), Rouva et al. (2016) Buzz Marketing has a positive and significant effect on Supply Chain Performance

Hypothesis 4: Buzz Marketing has a positive and significant effect on Supply Chain Performance.

\subsection{Relationship of Purchase Intention to Supply Chain Performance}

In this digital era, the customer's decision-making process can be influenced by social media, including influencing the decision to buy a product. According to Sawaftah et al. (2020), Oosterwijk et al. (2005), Rabidas et al. (2019) peer influence affects consumer attitudes towards a product, by increasing positive attitudes towards the product it will increase the intention to buy the product. According to Gunawan et al. (2015), Haryani et al. (2015) explain several factors that have implications for social media users. According to Shin et al. (2016), Trivedi et al. (2017) Purchase Intention has a positive and significant effect on Supply Chain Performance. According to Vianna et al. (2016), Purchase Intention has a positive and significant effect on Supply Chain Performance.

Hypothesis 5: Purchase Intention has a positive and significant effect on Supply Chain Performance.

\section{Research}

In this study using quantitative methods and data analysis techniques Structural Equation Modeling using SmartPLS 3.0 software. The sample selection method used the snowball sampling method. Online questionnaires were sent to respondents as many as 120 Freight Forwarders in DKI Jakarta. Based on theoretical studies and previous studies, the research model is structured in Fig. 1.

\section{Result and Discussion}

\subsection{Reliability Test}

According to Purwanto et al. (2020) the reliability requirement is a measure of the stability and consistency of the results (data) at different times. To test the reliability of the construct in this study used the value of composite reliability. A variable is said to meet construct reliability if it has a composite reliability value $>0.7$ and Cronbach's Alpha value $>0.6$ has a good level of reliability for a variable (Purwanto et al., 2019). The composite reliability value of each indicator can be seen in Table 1 below. 


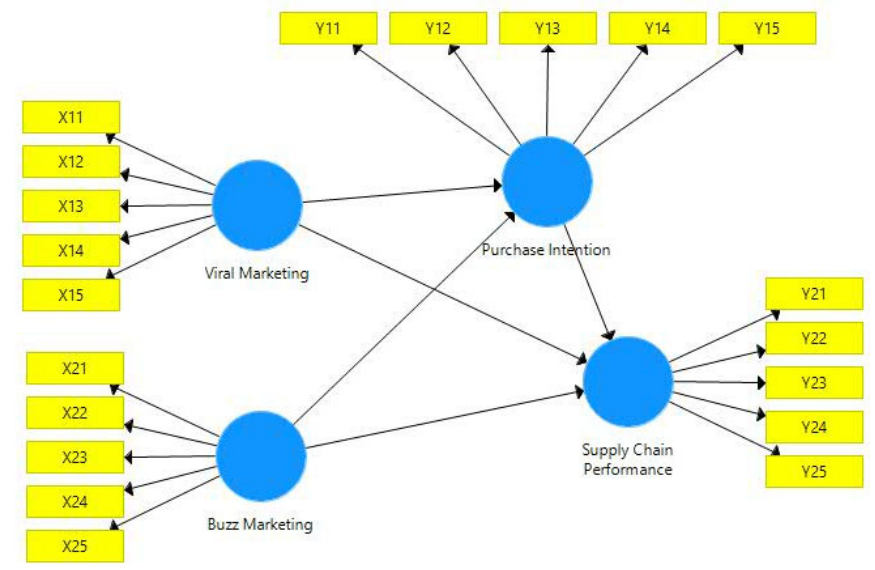

Fig. 1. Research Model

Table 1

The results of the reliability

\begin{tabular}{lll}
\hline Variables & Cronbach's Alpha & Composite Reliability \\
\hline Viral Marketing & 0.976 & 0.988 \\
Buzz marketing & 0.995 & 0.996 \\
Purchase Intention & 0.988 & 0.977 \\
Supply Chain Performance & 0.876 & 0.916 \\
\hline
\end{tabular}

In Table 1, it can be seen the results of the reliability test analysis using the SmartPLS tool which states that all composite reliability values are greater than 0.7 , which means that all variables are reliable and have met the test criteria. Furthermore, the value of Cronbach's omission also shows that all Cronbach's 'alpha' values are more than 0.6 and this indicates the level of reliability of the variable has also met the criteria.

\subsection{Convergent Validity}

Measurement can be categorized as having convergent validity if the loading factor value is $>0.7$ (Purwanto et al., 2021). Fig. 2 shows that all loading factors have a value of $>0.7$, so it can be concluded that all indicators have met the criteria for convergent validity, because indicators for all variables have not been eliminated from the model.

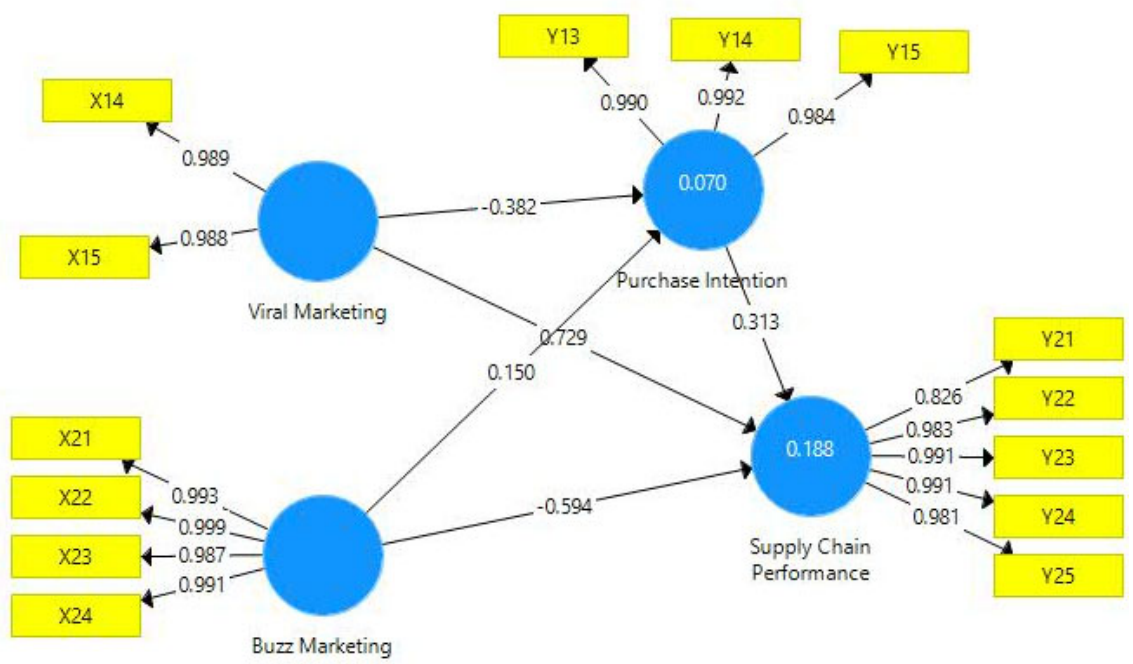

Fig. 2. Convergent Validity 


\subsection{Discriminant validity testing}

Based on Table 2, the AVE value for all variables is $>0.50$. So it can be said that the measurement model has been valid with discriminant validity. In addition, discriminant validity was also carried out based on the Furnell Larker criterion measurement with the construct. If the construct correlation in each indicator is greater than the other constructs, it means that latent constructs can predict indicators better than other constructs (Purwanto et al., 2019).

Table 2

The results of AVE

\begin{tabular}{lll}
\hline Variables & AVE \\
\hline Viral Marketing & 0.988 \\
Buzz marketing & 0.996 \\
Purchase Intention & 0.918 \\
Supply Chain Performance & 0.916 \\
\hline
\end{tabular}

\subsection{Structural model (inner model)}

The structural model (inner model) is the pattern of the relationship between the research variables. Evaluation of the structural model is by looking at the coefficients between variables and the value of the coefficient of determination (R2). The coefficient of determination (R2) essentially measures how far the model's ability to explain variations in the dependent variable is. In this study, the adjusted r-square value (adjusted R2) is used, because it has more than two independent variables.

Table 3

The results of R-square adjusted

\begin{tabular}{ll}
\hline Variables & R-square adjusted \\
\hline Purchase Intention & 0.070 \\
Supply Chain Performance & 0.188 \\
\hline
\end{tabular}

In Table 3, it can be explained that the adjusted R2 value of the independent variables of viral marketing and buzz marketing on the dependent variable of purchase intention is 0.070 . This value is categorized as weak. The variables of viral marketing and buzz marketing contributed to the dependent variable of purchase intention by $7 \%$ while the remaining $93 \%$ was influenced by other variables not discussed in this study. The adjusted R2 value of the independent variables viral marketing, buzz marketing and purchase intention on the dependent variable supply chain performance is 0.188 . This value is categorized as weak. The variables viral marketing, buzz marketing and purchase intention contributed to the dependent variable supply chain performance by $18.8 \%$ while the remaining $81.2 \%$ was influenced by other variables not discussed in this study.

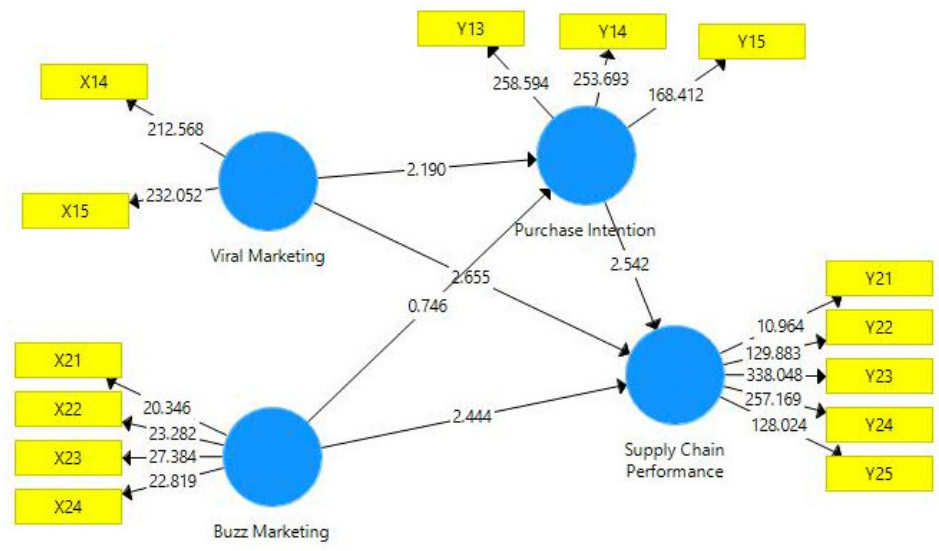

Fig. 3. Hypotheses Testing

\subsection{Hypothesis test}

According to Purwanto et al. (2021) After a research model is believed to be fit, a hypothesis test can be performed. The next step is to test the hypothesis that has been built in this study. The following are the results of the data test using bootstrapping. Hypothesis testing in this study can be known through regression weight by comparing the p-value with a significance level of $5 \%(\alpha=5 \%)$. The hypothesis is said to be significant if it has a probability value (p-value) $<5 \%$. 
Table 4

Hypotheses Testing for Direct Effect

\begin{tabular}{lcc}
\hline Hypotheses & P - Value & \\
\hline Viral marketing $\rightarrow$ purchase intention & 0.028 & Result \\
Viral marketing $\rightarrow$ supply chain performance & 0.008 & Significant \\
Buzz marketing $\rightarrow$ purchase intention & 0.046 & Significant \\
Buzz marketing $\rightarrow$ supply chain performance & 0.015 & Significant \\
Purchase intention $\rightarrow$ supply chain performance & Significant & Significant \\
\hline
\end{tabular}

\subsection{The relationship between Viral marketing and purchase intention}

Based on the results of data analysis using SmartPLS, the p value is $0.028<0.050$ so it can be concluded that Viral marketing has a significant effect on Purchase Intention, an increase in the Viral marketing variable will have a significant effect on increasing the Purchase Intention variable and a decrease in the Viral Marketing variable will have a significant influence on the decrease in the Purchase Variable. intention. These results are not in line with the research conducted by According to Rouva et al. (2016), Satrio et al. (2020), Shin et al. (2016), Trivedi et al. (2017), Vianna et al. (2016) that Viral marketing has a positive and significant effect on purchase intention. Viral marketing is one of the advantages of social media compared to traditional media. According to Carl et al. (2006); Rudyanto et al. (2021); Haudi et al. (2021) viral marketing is creating marketing messages or advertising that aims to be disseminated through online word of mouth (WOM).

\subsection{The relationship between Viral marketing and supply chain performance}

Based on the results of data analysis using SmartPLS obtained p value of $0.008<0.050$ so it is concluded that Viral marketing has a significant effect on supply chain performance, an increase in Viral marketing variables will have a significant effect on increasing supply chain performance variables and a decrease in Viral marketing variables will have a significant effect on decreasing supply chain performance variables. These results are not in line with the research conducted by According to Carl et al. (2006), Goyal et al. (2018), Gunawan et al. (2015), Haryani et al. (2015) that Viral marketing has a positive and significant effect on supply chain performance. Sharing information, such as photos, videos or articles, which was previously done on certain Web Sites, has now migrated to social media. The basic difference between viral marketing and online WOM is not only the perception or opinion of a product or company that is spread in viral marketing, but more focused on sharing marketing messages that represent a brand. According to Satrio et al. (2020), Shin et al. (2016) there are several factors that influence advertising on social media to get a positive attitude from social media users, namely informative, entertaining, self-brand congruity, and peer influence.

\subsection{The relationship between buzz marketing and purchase intention}

Based on the results of data analysis using SmartPLS, the p value is $0.046<0.050$ so it can be concluded that Buzz marketing has a significant effect on Purchase Intention, an increase in the Buzz Marketing variable will have a significant influence on the increase in the Purchase Intention variable and a decrease in the Buzz Marketing variable will have a significant effect on the decrease in the Purchase Variable. intention. These results are not in line with the research conducted by According to Liu et al. (2019), Mohr et al. (2017), Notaranonio et al. (2009), Sawaftah et al. (2020), Oosterwijk et al. (2005) Buzz marketing has a positive and significant effect on purchase intention. According to Rabidas et al. (2019), Reichstein et al. (2019) Social Media communicates well with consumers, companies can improve relationships with consumers, where social media allows for communication with many people and two-way communication. By conducting public engagement through communication with social media, it will affect the improvement of the relationship between the organization and consumers. It is also influenced by the organizational character that consumers perceive when communicating through social media, a sincere organizational character that makes the organization's relationship with consumers closer. In the research of Oosterwijk et al. (2005), Rabidas et al. (2019); Purba et al. (2021); Wijaya et al. (2021) interaction between organizations and consumers through social media has an effect on increasing brand relationship quality through mediating emotional influences.

\subsection{The relationship between Buzz marketing and supply chain performance}

Based on the results of data analysis using SmartPLS obtained p value of $0.015<0.050$ so it can be concluded that Buzz marketing has a significant effect on supply chain performance, an increase in the marketing buzz variable will have a significant effect on increasing supply chain performance variables and a decrease in the buzz marketing variable will have a significant effect on decrease in supply chain performance variables. This result is not in line with the research conducted by According to Oosterwijk et al. (2005), Rabidas et al. (2019), Reichstein et al. (2019) that Buzz marketing has a positive and significant effect on supply chain performance. According to Carl et al. (2006), Goyal et al. (2018) buzz marketing uses WOM to share consumer experiences, opinions, or information about a brand or company with fellow social media users . The study also explained that buzz marketing is divided into two types, namely, consumers to consumers or buzzers to consumers. According to Notaranonio et al. (2009), Sawaftah et al. (2020) Buzzer is a brand ambassador or person who appoints a company to represent the company. One of the reasons customers join social media is to share their experiences 
with other users. People who provide online recommendations in the form of glimpses of products or experiences after using the product are called influencers, while people who seek online recommendations are called adopters.

\subsection{The relationship between purchase intention and supply chain performance}

Based on the results of data analysis using SmartPLS obtained p value of $0.011<0.050$ so it can be concluded that purchase intention has a significant effect on supply chain performance, an increase in the purchase intention variable will have a significant effect on increasing supply chain performance variables and a decrease in the purchase intention variable will have a significant effect on decreasing supply chain performance variables. This result is not in line with the research conducted by According to Sawaftah et al. (2020), Oosterwijk et al. (2005), Rabidas et al. (2019) that purchase intention has a positive and significant effect on supply chain performance. In this digital era, the customer's decision-making process can be influenced by social media, including influencing the decision to buy a product. According to Sawaftah et al. (2020), Oosterwijk et al. (2005), Rabidas et al. (2019) peer influence affects consumer attitudes towards a product, by increasing positive attitudes towards the product it will increase the intention to buy the product. According to Gunawan et al. (2015), Haryani et al. (2015) explain several factors that have implications for social media users. The first is social media that is always on, social media users can be divided into two, namely passive and active shopping. According to Satrio et al. (2020), Shin et al. (2016) By using social media, marketers can provide this convenience to customers.

\section{Conclusion}

Based on data analysis, it was found that there is a positive influence between viral marketing and purchase intention, there is a positive influence between viral marketing and supply chain performance, there is a positive influence between buzz marketing and purchase intention. There is a positive influence between marketing buzz and supply chain performance. There is a positive influence between purchase intention and supply chain performance. Social media is a marketing communication tool that can be categorized based on the reasons or motivations of marketers using social media and the targets of marketing programs that can be achieved using social media. In an active shopping condition, customers will seek as much information as possible, both positive and negative information, to assist the decision-making process. While in passive shopping conditions, customers will get a stimulus from promotions carried out by marketers, family, friends, or online communities, to become active shopping. These stimuli can come continuously in social media. The marketer's implications for this evolution are that the brand must be able to spread and be flexible, the brand must establish communication with customers and potential customers at the beginning and end of the decision-making process, the brand must be visible in every possible place to increase customer awareness, and the brand must accept input from customer.

\section{References}

Carl, W. J. (2006). What's all the buzz about? Everyday communication and the relational basis of word-of-mouth and buzz marketing practices. Management Communication Quarterly, 19(4), 601-634.

Goyal, A. P. (2018). E-Viral Marketing Influence and Underlying Marketing Strategies: Social Relationship Variables. Indian Journal of Computer Science, 3(1), 37-57.

Gunawan, D. D., \& Huarng, K. H. (2015). Viral effects of social network and media on consumers' purchase intention. Journal of Business Research, 68(11), 2237-2241.

Haryani, S., \& Motwani, B. (2015). Discriminant model for online viral marketing influencing consumers behavioural intention. Pacific science review B: Humanities and social sciences, 1(1), 49-56.

Haudi, H., Rahadjeng, E., Santamoko, R., Putra, R., Purwoko, D., Nurjannah, D., ... \& Purwanto, A. (2022). The role of emarketing and e-CRM on e-loyalty of Indonesian companies during Covid pandemic and digital era. Uncertain Supply Chain Management, 10(1), 217-224.

Holdford, D. A. (2004). Using buzz marketing to promote ideas, services, and products. Journal of the American Pharmacists Association, 44(3), 387-396.

Leila, C., \& Abderrazak, G. (2013). The impact of the effectiveness of a buzz marketing campaign on the image, awareness and purchasing decision: The moderating role of involvement. Journal of Marketing Research \& Case Studies, $2013,1$.

Liu, H. H., \& Wang, Y. N. (2019). Interrelationships between viral marketing and purchase intention via customer-based brand equity. Journal of Business and Management Sciences, 7(2), 72-83.

Mohr, I. (2017). Managing buzz marketing in the digital age. Journal of Marketing Development and Competitiveness, 11(2), $10-16$.

Notarantonio, E. M., \& Quigley Jr, C. J. (2009). The effectiveness of a buzz marketing approach compared to traditional advertising: An exploration. Journal of Promotion Management, 15(4), 455-464.

Sawaftah, D., Calıcioglu, C., \& Awadallah, R. (2020). The relationship between viral marketing and consumer purchase intention, the moderator role of brand image and age: Evidence from smartphone users in North Cyprus. Management Science Letters, 10(6), 1307-1320.

Oosterwijk, L., \& Loeffen, A. (2005). How to use buzz marketing effectively. A new marketing phenomenon explained and made practical. 
Purwanto, A. (2021). Partial Least Squares Structural Squation Modeling (PLS-SEM) Analysis for Social and Management Research: A Literature Review. Journal of Industrial Engineering \& Management Research, 2(4), 114 - 123. https://doi.org/10.7777/jiemar.v2i4.168

Purwanto, A., Asbari, M., \& Santoso, T. (2021). Education Management Research Data Analysis: Comparison of Results between Lisrel, Tetrad, GSCA, Amos, SmartPLS, WarpPLS, and SPSS For Small Samples. Nidhomul Haq : Jurnal Manajemen Pendidikan Islam, 6(2), 382-399. https://doi.org/10.31538/ndh.v6i2.1575

Purwanto, A., Asbari, M., Santoso, T. I., Sunarsi, D., \& Ilham, D. (2021). Education Research Quantitative Analysis for Little Respondents: Comparing of Lisrel, Tetrad, GSCA, Amos, SmartPLS, WarpPLS, and SPSS. Jurnal Studi Dosen Dan Pembelajaran, 4(2), 335-348. https://doi.org/10.30605/jsgp.4.2.2021.1326

Prahiawan, W., Fahlevi, M., Juliana, J., Purba, J., \& Tarigan, S. (2021). The role of e-satisfaction, e-word of mouth and e-trust on repurchase intention of online shop. International Journal of Data and Network Science, 5(4), 593-600.

Prahiawan, W., Fahlevi, M., Juliana, J., Purba, J., Khamaludind, K., Syam, S., \& Lestari, S. (2022). The effect of supply chain quality perception and country of origin on Smartphones purchase intention of Indonesian consumers. Uncertain Supply Chain Management, 10(1), 277-284.

Rabidas, M. C., \& Bowen, G. (2019). Viral marketing consumer purchase intentions: A theoretical review. In 2nd International workshop on advances in social sciences. http://bit. ly/2TslGqi.

Reichstein, T., \& Brusch, I. (2019). The decision-making process in viral marketing-A review and suggestions for further research. Psychology \& Marketing, 36(11), 1062-1081

Rouva, E., Lalou, P., Skordoulis, M., \& Chalikias, M. (2016). Viral marketing analysis and evaluation: the case of the Greek consumer market. International Journal of Electronic Customer Relationship Management, 10(1), 28-38.

Rudyanto, R., Pramono, R., \& Purwanto, A. (2021). The influence of antecedents of supply chain integration on company performance. Bagchi, PK \& Chun HB (2005). Supply Chain Integration: a European survey. The International Journal of Logistics Management, 16(2), 275-294.

Satrio, D., Priyanto, S. H., \& Nugraha, A. K. (2020). Viral marketing for cultural product: The role of emotion and cultural awareness to influence purchasing intention. Montenegrin Journal of Economics, 16(2), 77-91.

Shin, S., Hwang, I., \& Min, J. Y. (2016). Effect of viral marketing in on-line mall review and power blog self-presentation on mediator variable word of mouth and apparel purchase behavior. The Research Journal of the Costume Culture, 24(5), 600-616.

Trivedi, J. (2017). The effect of viral marketing messages on consumer behavior. Journal of Management Research, 17(2), 84-98.

Vianna, K. A., de Mesquita, J. M. C., Linhares, M. R. S., \& Moreira, P. D. C. G. (2016). The relationship between viral marketing, purchase intention, and brand visibility: Study with Brazilian customers. In Rediscovering the Essentiality of Marketing (pp. 229-241). Springer, Cham.

Wijaya, O., Sulistiyani, S., Pudjowati, J., Kurniasih, N., \& Purwanto, A. (2021). The role of social media marketing, entertainment, customization, trendiness, interaction and word-of-mouth on purchase intention: An empirical study from Indonesian smartphone consumers. International Journal of Data and Network Science, 5(3), 231-238.

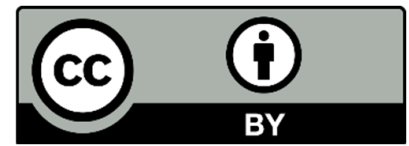

(C) 2022 by the authors; licensee Growing Science, Canada. This is an open access article distributed under the terms and conditions of the Creative Commons Attribution (CCBY) license (http://creativecommons.org/licenses/by/4.0/). 